\title{
Effects of Gender on Students' Academic Achievement in Public Secondary Schools in Marakwet East Sub County, Kenya
}

\author{
Charles K. Kisigot ${ }^{1}$, Prof. Paul A. Ogula ${ }^{2^{*}}$, Dr. Jennifer Munyua ${ }^{3}$ \\ ${ }^{I}$ Department of Post of Graduate Studies at the Catholic University of Eastern Africa \\ ${ }^{2}$ Faculty of Education, Department of Post Graduate Studies. The Catholic University of Eastern Africa \\ ${ }^{3}$ Department of Educational Psychology. The Catholic University of Eastern Africa
}

*Corresponding Author: Prof. Paul A. Ogula, Faculty of Education, Department of Post Graduate Studies. The Catholic University of Eastern Africa, Kenya

\begin{abstract}
The low number of students transiting to tertiary institutions coupled with the concerns by stakeholders motivated the researcher to investigate the effects of gender difference on the academic achievement of secondary school students in Marakwet East Sub County, Kenya. Accordingly, the research questions were; what is the level of academic achievement in public secondary schools in Marakwet East Sub County and; what is the relationship between gender and students' academic achievement? The study was anchored on constructivism theory by Jean Piaget and supported by Boyle (1994). The study adopted an embedded mixed methods research. Ex post facto Causal comparative research design was employed. The study focused on 18 public secondary schools, 18 Directors of Studies and 140 teachers within Marakwet East Sub County. The study used stratified and simple random sampling to select a sample of 72 secondary school teachers, 10 secondary schools, 10 directors of studies and 10 secondary school Principals. Data were collected through administering questionnaires to teachers, interviewing Principals and Directors of Studies, observation, and document analysis. Descriptive and inferential statistics were used to analyze data. Collected quantitative data was analyzed using ANOVA. Qualitative data were analyzed through thematic and in-depth descriptions of observed and recorded data. Frequency tables and graphs were used to present the data. This study found the need to implore education stakeholders to strive to embrace gender equity for enhanced academic achievements.
\end{abstract}

Keywords: Gender, Students, Academic, Achievement, Marakwet, Public, Secondary Schools.

\section{INTRODUCTION}

Many researchers have attempted to define and even carried out studies touching on gender as a factor in academics. Flynn (2012), for example defined gender as the range of physical, biological, mental and behavioural characteristics pertaining to and differentiating between masculinity and feminity. Gender is one of the personal variables with relationships to differences in motivational functioning and in self-regulated learning patterns in boys and girls. In the traditional times, there were some work reserved for boys and girls. These beliefs have been extended to educational settings. There are also vocations regarded as men's and women's. Kashu, (2014) has argued that gender related disparities have also characterized Kenyan education system at the national level, at regional level and at all levels of education from primary to university in favour of males. MOE (2005) reported that secondary school sub sector has been facing challenges, particularly unsatisfactory level of transition from secondary to tertiary particularly university, as well as serious gender and regional disparities with the quality of secondary education remaining low in the last decade. Government of Kenya Education officials and media have over the past couple of years published the top one hundred KCSE candidates at national, regional, county and sub county levels. The top of the lists have often been dominated by male candidates or males'-only schools apart from just but a few schools and sub counties where the performances have tilted slightly in favour of the female gender (MOE, 2014).

The socio-political and economic transitions that Kenya has gone through since independence in 1963 has given rise to inadequacies in the education sector as evidenced in the disturbing drawbacks of inequality based on sex, county and even between one school and another (Bogonko, 2010). Kenya government (MOE, 2007); Mondoh and Mujidi (2006) and UNESCO (2009) have reported boys' 
academic achievement to be better and on the rise at all levels. Social, political and economic variables may directly or indirectly influence students' academic achievements. Social and practical interactions, and provision and delivery of teaching learning services take place in developed or provided environments.

This calls for concerted efforts by stakeholders to encourage effective teaching and learning in secondary schools since they have relationships. Similarly, trends reviewed above worry intellectuals especially on the roles of males and females in social, political, scientific and technological development of a country, thus the need to do a study on them for information and informed decisions making.

\section{Statement Of The Problem}

The community environment is rich with socio-cultural activities and practices like traditional games and dances, female genital mutilation, cattle rustling, traditional marriage ceremonies and early marriages. Both boys and girls indulge in, practice and are actively involved in these rites which are highly regarded. Despite the many endeavors by government and stakeholders in education through community capacity building for embracing modern life and formal education; mobilizing resources through fund raisers and building more classrooms, the secondary schools have not produced adequate grades and numbers of form four secondary school students with requisite academic results and qualification grades in national examinations for joining tertiary or university education and training.

Unlike in all secondary schools in Marakwet east combined, where only 38 out of 654 candidates who sat for the $2017 \mathrm{KCSE}$ exams met the minimum university required entry points, and attaining a mean of grade $\mathrm{C}+$ equivalent to 7 points out of 12 maximum points or an ' $\mathrm{A}$ ' plain, other individual secondary schools or sub counties were graduating over hundred to tertiary institutions and university. Either, in 2016, out of 546, only 29 candidates scored C+ (plus) and above. It was one girls-only school that produced 19 of the 29 qualified candidates in the 2016 KCSE national examinations (SCDE, 2017). The mean grade for this year was a C-(an equal of 5 points). The 2015, 2014, and 2013 KCSE mean grades stood at D+ (an equivalent of 4 points) with majority of the schools registering poorer results that were characterized by missing marks or withheld results.

This can be attributed to a number of factors such as school, teachers, students' gender and surrounding environments. Cultural practices, like engaging in cattle rustling and perhaps early marriages, student/teacher absenteeism, and school dropout could be observable practices in the study area and might in one way or the other have contributed to the students' learning outcomes in KCSE. The secondary schools have continued to post poor examination results in the past ten years despite the above efforts. This show disparities in sexes is an area of interest to be studied to seek answers to existence of poor students' academic achievements. The results and achievements of secondary schools in this sub county (MOEST, 2016) indicates existence of declining trend in academic achievement compared with other secondary schools in entire Elgeyo Marakwet County. KCSE means of 4.35, 4.012, 3.87, 3.67 and 3.225 from 2015 to 2019 in such a long period is really challenging (MOEST, 2019). If this situation is left an unchecked and continuous for long it could lead to fewer graduates, lower skilled and knowledgeable human resources hence leading to socioeconomic underdevelopment of the study area. Therefore, this study sought to find out the effects of gender on secondary school students' academic achievements in Marakwet East Sub County, Kenya so that answers to existing gaps are developed.

\subsection{Research Questions}

The following research questions guided the study:

- What is the level of academic achievement in public secondary schools in Marakwet East Sub County?

- What is the relationship between gender and students' academic achievement in public secondary schools in Marakwet East Sub County?

\subsection{Research Hypothesis}

$\mathrm{H}_{1} \quad$ There is a relationship between gender and students' academic achievement in public secondary schools in Marakwet East Sub County. 


\section{THEORETICAL FRAMEWORK}

This study was based on sociocultural learning theory and constructivist theory. The theory of sociocultural learning was put forward by Lev Vygotsky (1978) whereas constructivist theory was by Boyle (1994). The socio cultural learning theory stated that human learning was a social affair that involved humans interacting in the processes or during learning. The constructivist worldview posited that learning was an active process. The student is an information constructor who actively constructs or creates their own subjective representations of objective reality and thought. This theory views learning as the active process of drawing meaning from experience (Semple, 2000). The responsibility of knowledge transfer lays with the learner, not the teacher. The learning environment designs based on this theory are student-centered, collaborative, cooperative, and experiential. Teachers serve as facilitators (Caine \&Caine, 1991). Learning environments should be safe, challenging, comfortable, social, and should enhance interaction. Learning opportunities need not take place in the classroom setting alone. They may also take place in hallways, outdoors, or during lunchtime (ibid). Moore (2014) explained the interactional constructivist theory that conceptualizes the learning environment into indoor, outdoor and neighbouring environments.

\subsection{Academic Achievement in Public Secondary Schools}

Boit et al. (2012) have argued that secondary school education equips the citizenry to reshape and eliminate inequality in society. Therefore, secondary school students' academic achievements is a pointer of the effectiveness of learning in schools as well as a major determinant of the well-being of youths and a nation (Yusuf \& Adigun, 2010). Secondary School Education in this regard plays an important role of creating substantive human resource base and for developing the individual and the nation.

It is more crucial today than never before, that secondary students are academically prepared to achieve competitive knowledge and technology. This is because, when they are not prepared, the later costs individuals and society can bear may be higher and bitter. For instance, high level of unemployment, lower earnings, early withdrawal from school leading to increased ignorance and thus health problems. Many studies across the globe have shown that there are many factors that affect academic performances. It is however not clear which factors can enhance academic achievements. The quality of learning facilities available within public secondary schools have effects on the quality of teaching and learning activities which in turn leads to attainment of good grades. There are definite variables that are really responsible for the constant underperformance or success of schools especially in national examinations.

In Marakwet east Sub County (MOES\&T, 2018) KCSE results and performances by secondary schools indicates a stagnating trend in academic achievements. Schools' performance in relation to other secondary schools in ElgeyoMarakwet County has shown underachievement. This has attracted much queries and discussions, some in low tones and that different concerned parties have focused on varied perspectives such as learning environment, attitudes on students' gender and poverty. This alarming issue in KCSE performance by secondary schools could be explained from cultural, social, and environmental viewpoints. Marakwet socio-cultural practices and belief systems differ from their Keiyo cousins and likewise to the learning environment and gender practices. Secondary students' academic achievement in the Sub County on the average has been showing steady drop in the recent past since the year 2010. For example, 2017 KCSE results for all the 18 secondary schools, had only 38 candidates meeting the minimum university entry points of a $\mathrm{C}+$ (plus or 7points). The mean score for the year is 3.395 , a " $D$ " grade which is equivalent to 3 points. Previously, in 2016 only 29 candidates from all the schools scored slightly above C+ (plus) and qualified to join university and that the mean was 3.333 a D plain (equivalent to 3 points). One girls-only school produced 19 out of the total 29 who joined universities that year (Marakwet East Sub County Education Report, 2018). The 2015 KCSE results were satisfactory because the sub county realized a mean equivalent to grade 'C' plain (6 points). The means were 'C-'minus (4points) 2014; and a $\mathrm{D}+(4.48)$ in 2013. This can be attributed to a number of factors such as learning environment (school), the teachers and the students' gender. Absenteeism, school dropout, engagement in outlawed cattle rustling and perhaps early marriages is observed and reported by the education officials in the study area. These might in one way or the other have contributed to the students' learning outcomes KCSE. Stakeholders have made 
efforts to provide requisite materials and equipment, paid fees and other school levies, mobilized resources and built more secondary schools. The students attend school each other school term and sit for the internal (formative) and national (summative) evaluation or examinations. The study established that school environment and peer influence made significant contribution to the students' academic achievement. It is hoped that the findings of this study will be useful to teachers, principals, students and parents to gain more insight into the psychosocial factors that affect students' academic achievement and therefore help improve their academic achievement.

\subsection{Gender Differences and its Effects on Academic Achievement}

Issues of gender and students' academic achievements have remained a controversial one for a long time world over. In the USA researchers have argued that males performed better than females in academics, while others have argued that the reverse was the case. For example, Calsmith (2007, p.75) had explained that the influence of gender and differences in academic achievement was a complex task, thus many studies appeared to be contradictory.

Feldman (2010) conducted a study in USA on the effect of gender differences on academic achievement in Early Childhood Kindergarten Class. This was attributed to the fact that there was an assumption that male children were more intelligent than the female students. The Feldman study established that children of both sexes start school with roughly similar potential to learn. Their scores on IQ tests were approximately equivalent when gender difference was controlled. The study however found out that girls' advantage in reading became apparent by third grade and gender differences continued to increase through eighth grade. The study however established that the test scores of female students decrease over time when children move up the ladder in the education arena.

From Feldman (2010) study it was evident that there are environmental factors that contributed to decreased intelligence quotient of female students in their education and therefore this study was conducted to investigate the environmental factors influencing the gender difference in academic achievement of secondary school students in Marakwet east Sub County of ElgeyoMarakwet County, Kenya. The reviewed study was conducted in USA a developed country in terms of educational investment as compared to Kenya, a developing country. USA also have different cultural differences to Kenya. The study in USA was also conducted in 2010 and therefore necessitating a more recent study due to changes that have occurred in education in relation to educational development.

Earlier, Shelton (2008) conducted a study in the United Kingdom on gender difference in academic achievement of different subjects from Kinderngaten level. Another context where overall enrollments are high for both boys and girls (Shelton, 2008). While there was no significant difference in the number of girls and boys meeting the mathematics benchmark ("Level 2," the level expected of seven-year-olds), there was a 10-percentage-point gap favouring girls in reading (Shelton, 2008).

Anderson (2012) investigated the Gender Differences in Student Achievement and Teacher Training Characteristics in the Gulf Cooperation Council Countries. Gender differences in student achievement, and the inferred educational disadvantage of boys, was the context of the "crisis for boys" discourse in education. The researcher observed with great concern that there has been Boys' underachievement in the United Arab Emirates (UAE). The researcher argued that this could be attributed to the training characteristics of expatriate male teachers in boys' schools. The UAE is a member of the Gulf Cooperation Council (GCC) countries which also includes Bahrain, Kuwait, Oman, Qatar, and Saudi Arabia.

Akpochafo (2010) reported that there was gender bias in Nigeria like in many African societies, a situation in which cultural beliefs and structural arrangement favoured men over women as was witnessed in many elective positions contestable by men and women. Electorates see women as always not fit to rule or govern since men are involved. The idea that women should be under and submissive to men have created a negative influence in the life of women. In support of this, Anele (2008, p.73) explained that the socio-cultural practices of the African societies have placed men on positions that gives them domineering influence over women. Intrinsically, there is practically no significant difference in the intelligence between male and female that could be traceable to gender difference. The fact that men are even superior sex does not mean that they are artistically better than women (Okoye' 1987). Okeke (2007) equally observed that the school curriculum in Nigeria was not 
gender fair since its contents reflected mainly the concerns of males; sciences careers portrayed masculine images in the curriculum as well as females suffering from teacher overtly and covertly, knowingly and unknowingly.

Omenge and Nasango (2010, p. 327) in their study in Kenyan secondary schools on effects of socialization as regards to gender roles on academic achievements of girls found out that there were myriad of factors to be blamed for the low academic performance of female students. The gendered roles included domestic chores and biased upbringings that portrayed boys as superior to girls. The results of the study by Omenge and Nasango (2010, p.327) linked female students' participation in domestic roles to their low participation in class which resulted in low academic achievements.

It was obvious from the related literature reviewed that the role of gender in the academic achievement of students is a controversial issue. This is because some research findings revealed that gender plays active roles in students' academic achievement. Others revealed otherwise. This therefore leads to investigation of effects of gender on secondary school students' academic achievements.

\section{RESEARCH METHODOLOGY}

This study has employed an embedded mixed methods research design. This entailed a quantitative methodology of causal comparative that allowed the researcher to examine the relationships between the two variables of gender and academic achievement. The study also employed phenomenological type of qualitative research design. The target population was 10 secondary schools, all the 140 teachers, 10 secondary school principals and 10 School Directors of Studies. The researcher also targeted Kenya Certificate of Secondary Examination achievement or results (KCSE) because the sub county has been scoring very low performance in in the years compared to other neighbor sub counties.

Using Krejcie and Morgan formula a sample of 103 teachers out of 140 teachers were selected. Teachers in the participating schools were stratified into three strata namely; mixed schools, girls' schools and boys' secondary schools. Later on proportionate sampling was used to select teachers from each of the categories of schools. For boys schools proportional sampling was done as follows $42 / 140 * 103=30$; for girls schools $44 / 140 * 103=32$; and mixed schools $54 / 140 * 103$. Simple random sampling was then used to select individual teachers from each of the categories. Directors of Studies and Principals were purposively picked. Research instrument used for the study included; Questionnaires, Observation schedule, Interview schedules, and Document analysis,

\subsection{Findings}

\section{- Level of Academic Achievements of Public Secondary Schools in Marakwet East Sub County}

The first research question sought to determine the level of academic achievement in public secondary schools in Marakwet East Sub County. A document analysis was done to obtain KCSE performances in schools in the years 2016 - 2019. Data from the document analysis guide regarding the level of academic achievement in the three types of schools under study namely boys' schools, girls' schools and mixed schools is presented in Table 1.

Table1. Level of Academic Achievement of Public Secondary Schools in Marakwet East Sub County

\begin{tabular}{|l|l|l|l|l|l|l|}
\hline & \multicolumn{2}{|c|}{ Boys } & \multicolumn{2}{c|}{ Girls } & \multicolumn{2}{c|}{ Mixed } \\
\hline & Mean & SD & Mean & SD & Mean & SD \\
\hline $\mathbf{2 0 1 6}$ & 4.53 & 0.872 & 3.3 & 0.361 & 3.15 & 0.511 \\
\hline $\mathbf{2 0 1 7}$ & 4.67 & 0.937 & 3.37 & 0.363 & 3.16 & 0.573 \\
\hline $\mathbf{2 0 1 8}$ & 5.34 & 1.04 & 3.93 & 0.366 & 3.63 & 0.672 \\
\hline $\mathbf{2 0 1 9}$ & 4.89 & 0.211 & 4.97 & 0.291 & 4.18 & 0.501 \\
\hline
\end{tabular}

Findings in Table 1 indicated that male gender schools performed better than the girls' schools and mixed schools in the 2016 KCSE. Data indicate that boys' schools had an average mean of 4.53 with a positive deviation of 0.872 from the overall mean in 2016. Girls had a mean of 3.3 while mixed schools had a mean of 3.15. This result shows that boys' schools performed better than girls and mixed schools. The range between the high and low performers in 2017 was 1.51 as indicated in 
Table 1 . In this year just like the preceding year boys schools $($ Mean $=4.67)$ performed better, the boys' schools were followed by girls (Mean $=3.37$ ) then lastly the mixed schools at 3.16. It is useful to note that the schools recorded an upward trend in performance. Table 1 indicated that in 2018 mixed schools were the low performers while boys' schools were the high performers in KCSE. Lastly but importantly Table 1 in 2019 indicated that girls performed better (Mean = 4.97) as compared to boys $($ Mean $=4.88)$ and mixed schools $($ Mean $=4.18)$.

These findings indicated that male gender performed better than the other schools in all the years under study apart from 2019 in which female achievement was higher than males. Of critical importance is that mixed gender were out smarted by the other gender in all the years under study.

\section{- Relationship between Gender and Academic Achievement of Public Secondary Schools in Marakwet East Sub County}

The second research question sought to determine the relationship between gender and students' academic achievement in public secondary schools in Marakwet East Sub County. The KCSE performances in schools in the years 2016 - 2019 was used to analyze this data. Data was rated using a 12 point scale $(1-12)$. Table 2 presents this data;-

Table2. Relationship between Gender and Academic Achievement

\begin{tabular}{|c|c|c|c|c|c|c|c|c|c|}
\hline & \multicolumn{3}{|l|}{ Boys } & \multicolumn{3}{|l|}{ Girls } & \multicolumn{3}{|l|}{ Mixed } \\
\hline & Mean & SD & Grade & Mean & SD & Grade & Mean & SD & Grade \\
\hline 2016 & 4.53 & 0.872 & C- & 3.3 & 0.361 & D & 3.15 & 0.511 & $\mathrm{D}$ \\
\hline 2017 & 4.67 & 0.937 & C- & 3.37 & 0.363 & D & 3.16 & 0.573 & $\mathrm{D}$ \\
\hline 2018 & 5.34 & 1.04 & C- & 3.93 & 0.366 & $\mathrm{D}+$ & 3.63 & 0.672 & $\mathrm{D}+$ \\
\hline 2019 & 4.89 & 0.211 & C- & 4.97 & 0.291 & C- & 4.18 & 0.501 & D+ \\
\hline
\end{tabular}

Table 2 indicated that there was a varied level of performance in the schools in relation to the students' gender. The relationship based on the means indicate that the boys only gender performed better than the girls only gender and the boys and girls (mixed gender). The boys' gender maintained a mean of $4.6-5.3$ throughout the four years period under study. Statistical tests that were performed indicated whether the means within the subjects were or not. Descriptively it is worth mentioning that the boys were superior. Possible reasons to explain this may be linked to the great efforts that the communities have put in place to improve the boy child. This comes at a backdrop of spirited efforts to improve the girl child status in the society. The question that this study begs to ask is whether the efforts to raise the girl child left the girl child in the comfort zone? And that, this may have brought a spirited fight by the boys to challenge the girls. Girls performances in the 4 years period that was analyzed indicated that there performances ranged from $3.3-4.9$. Unlike the boys' performance that did not show a steady improvement, girls' performances showed a continuous improvement which was positive. As stated earlier the girls' performances were lower as compared to the boys' performance but better than the mixed gender. Lastly, the mixed gender performances were lower as compared to the boys only and girls only gender. Past researches have shown that majority of these coeducational schools don't perform at similar levels with boys and girls schools. This study has similar findings indicating the low performances as compared to the other schools. Possible reasons may be linked to issues of discipline specifically boy - girl relationship, poor supervision given that most of these schools are day schools.

These findings are similar to Oludipe (2012) study on gender difference in Nigerian junior secondary students' academic achievement in basic science. The main purpose of this study was to investigate the influence of gender on Junior Secondary students' academic achievement in basic science using cooperative learning teaching strategy. Findings of this study revealed that there was no significant difference in academic achievement of male and female students at the pretest, posttest, and delayed posttest levels respectively. This research suggested that in order to encourage more women into pure sciences, and science-oriented courses, interventions need to be designed that focus not only on the academic achievement of girls but also in how to make science-related occupations more interesting for young, high achieving girls.

Similarly Mburu (2013) study on effects of the type of school attended on students' academic performance in Kericho and Kipkelion Districts, Kenya aimed at finding out the effects of the type of 
Effects of Gender on Students' Academic Achievement in Public Secondary Schools in Marakwet East Sub County, Kenya

school attended on male and female students, academic performance in Kenya. The major findings of the study were that the type of school attended affected student s' academic performance as majority of the girls who qualified to join tertiary institution were from single - sex schools.

\section{$\mathrm{H}_{2}$ There is a Relationship between Gender and Students Academic Achievement}

The alternative hypothesis $\mathrm{H}_{1}$ was there is a relationship between gender and students' academic achievement. Descriptive statistics was conducted to observe the distribution of the data. Table 3 displays the summary of the descriptive statistics

Table3. Descriptive Statistics for $\mathrm{H}_{4}$

\begin{tabular}{|l|l|l|l|l|l|l|l|l|}
\hline \multicolumn{9}{|c|}{ Descriptives } \\
\hline & $\mathbf{N}$ & Mean & $\begin{array}{l}\text { Std. } \\
\text { Deviation }\end{array}$ & $\begin{array}{l}\text { Std. } \\
\text { Error }\end{array}$ & $\begin{array}{l}\text { 95\% Confidence Interval } \\
\text { for Mean }\end{array}$ & Minimum & Maximum \\
\cline { 3 - 8 } & & & & $\begin{array}{l}\text { Lower } \\
\text { Bound }\end{array}$ & $\begin{array}{l}\text { Upper } \\
\text { Bound }\end{array}$ & \\
\hline boys & 3 & 4.8567 & .39929 & .23053 & 3.8648 & 5.8486 & 4.40 & 5.14 \\
\hline girls & 3 & 3.8933 & .51733 & .29868 & 2.6082 & 5.1785 & 3.30 & 4.25 \\
\hline mixed & 4 & 3.5300 & .21587 & .10794 & 3.1865 & 3.8735 & 3.31 & 3.73 \\
\hline Total & 10 & 4.0370 & .67492 & .21343 & 3.5542 & 4.5198 & 3.30 & 5.14 \\
\hline
\end{tabular}

As indicated in Table 3 the students achievement was looked at in view of 10 schools which were sub divided into three genders namely boys, girls and mixed. The dependent variable which was students' academic achievement had a mean of $4.86, \mathrm{SD}=.399$ in boys' schools, $3.89, \mathrm{SD}=.517$ in girls' schools and 3.53, $\mathrm{SD}=.216$ in mixed schools.

Table4. Test of Homogeneity of Variances

\begin{tabular}{|l|l|l|l|}
\hline \multicolumn{5}{|c|}{ Test of Homogeneity of Variances } \\
\hline \multicolumn{5}{|c|}{ Mean } & df2 & Sig. \\
\hline Levene Statistic & df1 & 7 & .153 \\
\hline 2.485 & 2 & 75 & \\
\hline
\end{tabular}

A requirement for the ANOVA test is that the variances of each comparison group are equal. This was tested this using the Levene statistic. Table 4 on the Test of Homogeneity of Variances provides the Levene's Test to check the assumption that the variances of the three types of school are equal; i.e., not significantly different. Finding indicate that the Levene's test is not significant; F $(2,7)=2.485$, $p$ $=.153$ at the .05 alpha level. Thus, the assumption of homogeneity of variance is met (i.e., not violated) for this sample. This implies that the requirement of homogeneity of variance has been met, and the ANOVA test can be considered to be robust.

Table5. ANOVA Output for $\mathrm{H}_{4}$

\begin{tabular}{|l|l|l|l|l|l|}
\hline \multicolumn{9}{|c|}{ ANOVA } \\
\hline & Sum of Squares & df & Mean Square & F & Sig. \\
\hline Between Groups & 3.106 & 2 & 1.553 & 10.936 & .007 \\
\hline Within Groups & .994 & 7 & .142 & & \\
\hline Total & 4.100 & 9 & & & \\
\hline
\end{tabular}

A one-way between groups analysis of variance was conducted to explore the relationship between gender and students' academic achievement. The gender was divided into three groups (boys' gender; girls' gender; and mixed gender). There was a significant difference at the pvalue at 0.007 , which is $\mathrm{p}<.05$ students' academic interpretation in the three genders $\mathrm{F}(2,7)=10.936, \mathrm{p}(0.007)<.05$.

The results in Table 5 indicated that boys or boys' schools had a better mean of 4.86 as compared to girls 3.89 and mixed schools 3.53 which was statistically significant. Figure 1 shows the distribution of the students' academic achievement across the genders. 


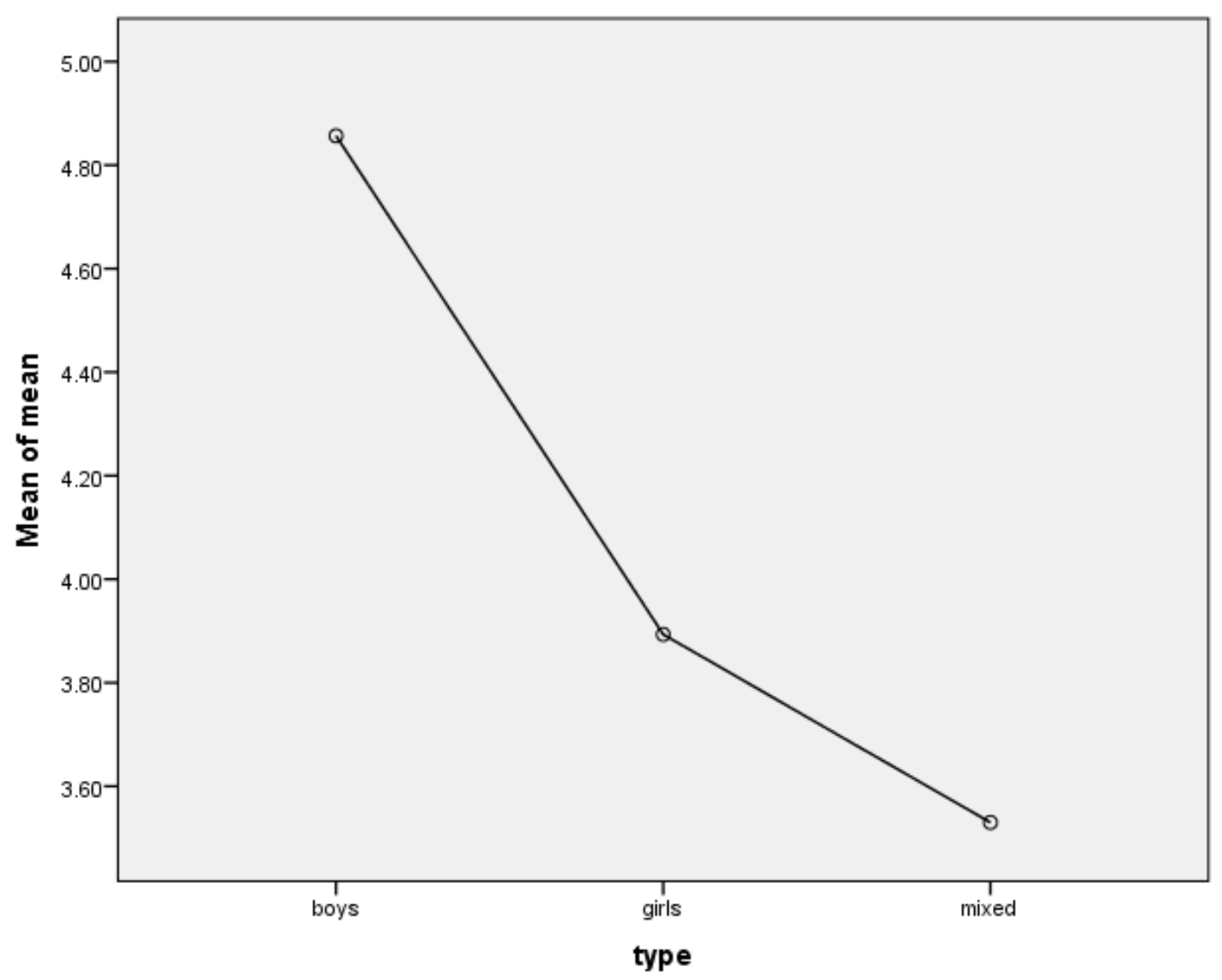

Figure1. Scree Plot of the Students' Academic Achievement as per the gender

Findings have indicated that the ANOVA was significant, allowing to accepting the alternative hypothesis, and indicating that there is a statistically significant relationship between students' academic achievement and gender. In the USA researchers have argued that males perform better than females in academics, while others have argued that the reverse is the case. For example, Calsmith (2007, p.75) has explained that the influence of gender and differences in academic achievement is a complex task, thus many studies appear to be contradictory. He said a tremendous work has been done in an attempt to find out potential causes of differences between girls' and boys' academic performances in Social Sciences and this has clearly demonstrated that male students are superior to their female counterparts in qualitative courses. Ayayo (2007), in an investigation spanning twelve industrialized countries argued that the ability of both male and female students in their general academic achievements revealed that males were superior over females. This superiority was not confining to USA alone. This confirmed that the level of instruction held constant males achieved higher levels than females. She attributed this to difference in achievement to the school environment and programmes, and opined that prior to attending school, general intelligence of girls was higher than that of boys but the position gradually reversed with the findings. UNESCO Report, (2000) observed that in most societies, gender has roles based on the women, preventing their participation in, and benefiting from development efforts This has created bigger psychological alienation or depression in the minds of female students (Joel \&Aride, 2006). This has resulted in boys dominating Social Studies, Chemistry, Physics, and Mathematics and Environmental studies classes while the girls go into reading languages and Arts.

\subsection{Summary of the Findings}

The research question determined the relationship between gender and students' academic achievement in public secondary schools in Marakwet East Sub County. The relationship based on the means indicate that the boys only gender performed better than the girls only gender and the boys and girls (mixed gender). Unlike the boys' performance that did not show a steady improvement, girls' performances showed a continuous improvement which was positive. As stated earlier the girls' performances were lower as compared to the boys' performance but better than the mixed gender. 
Lastly, the mixed gender performances were lower as compared to the boys only and girls only gender. Past researches have shown that majority of these coeducational schools don't perform at similar levels with boys and girls schools. This study has similar findings indicating the low performances as compared to the other schools. Possible reasons may be linked to issues of discipline specifically boy - girl relationship, poor supervision given that most of these schools are day schools.

A one way ANOVA was conducted to establish the relationship between gender and students' academic achievement. A one-way between groups analysis of variance was conducted to explore the relationship between gender and students' academic achievement. There was a statistically significant difference at the $\mathrm{p}<.05$ students' academic achievement in the three genders $\mathrm{F}(2,7)=10.936, \mathrm{p}<$ .05 . Findings have indicated that the ANOVA was significant, allowing to accepting the alternative hypothesis, and indicating that there is a statistically significant relationship between students' academic achievement and gender.

\section{CONCLUSION}

The findings of this study has revealed that there was a relationship between students' gender and academic achievement. It has also revealed that students' gender have effects on secondary students' academic achievement. Notably, boys' gender and girls' gender were performing better than the mixed gender. Lower performance of girls' and mixed gender as compared to boys is attributed to cultural issues such as early pregnancies, early marriages and house chores that are associated to girls in day's schools. The implication, therefore, is those female learners are at a more considerable disadvantage due to cultural issues and the limited provision of equal opportunities in the learning environment.

\section{RECOMMENDATIONS}

So as to improve the performance of both male and female students, all genders need to be provided with equal opportunities in the learning environment. There is need to avail more teaching and learning resources particularly in the sciences. Through the CDF mixed schools should be provided with funds for the construction of laboratories.

\section{REFERENCES}

[1] Anderson,D.R. (2012). “The Importance of Mentoring Programmes to women's career advancement in biotechnology", Journal of Career Development, vol. 32 No.11 pp60-73.

[2] Ayayo, O.(2007). Effect of gender attitude on academic performance in economics: An Unpublished M.Ed. Dissertation, University of Calabar.

[3] Adewuyi, (2012). International Journal of Sustainable Built Environment. 1(2), 167-176, 2012. Nigeria

[4] Adeyemi, T.O.(2008). The influence of class-size on the Quality of Output in Secondary Schools in Ekiti State, Nigeria. Pakistan Journal of Social Sciences. 5(2):202-208.

[5] Akpochafo, W.P.,(2010). Social Studies and FeministIssues for teacher Education. Benin city:Justice Jeco Press and Publishing Ltd.

[6] Anele, D. (2008). The Place woman in human existence: A critial inquiry. In Sunday Vanguard of August 31,21 .

[7] Boit, M., Changach, J.K., \& Njogi, I.A., (2012). The influence of Examinations on the stated curriculum Goals. American International Journal of Contemporary Reasearch, 2(2): 179-182

[8] Bogonko, S.(2010). Impact of Free Day Secondary Education Funding on student Enrolment, KCSE Academic Achievement in Gucha South Sub County, Kenya. Journal of Education, Society and Behavioural Science, 1-12, 2019.

[9] Boyle, T. (1994). Designing for usability and effectiveness in a Resource Rich Learning System. EastWest Journal of Computers in Education.

[10] Calsmith, N. S. (2007). Gender Differences in academic Performance. Journal of Experimental Psychology, 6(3), 44-50

[11] Flynn, J. (2012). Are we getting Smarter? Rising IQ in the twenty-first century.University of Otago.

[12] Joel, A. \& Aride, U. (2006). Social interaction and social relationship in school children.New York:Harcourt-brace and Jovanovich Inc.

[13] Kashu, J.N. (2014).Survey on gender and academic performance in secondary schools in Kenya.Doctorate Dissertation. University of Nairobi, Kenya. 
[14] Mburu, D. N. (2013). Effects of the type of school attended on students' academic performance in Kericho and Kipkelion districts, Kenya.

[15] MOEST, (2019). Sessional Paper No.1 of 2019: Policy Frameork for Reforming Education and Training for sustainable Development in Kenya.

[16] MOE. (2017).Kenya Certificate of Secondary Education. Nairobi, Kenya

[17] MOE, (2015). Republic of Rwanda TVET Policy. Kigali Rwanda

[18] MOEST, (2007). Dakar, Senegal April 2000 Policy Framework for Action.

[19] Moore, C. \& Riegle-Crumb, C. (2014). The gender gap in high School Physics: Considering the Context of Local Communities: Social Science quarterly. HHS Public Access.

[20] Okeke, E. A. C. (2007). Sex difference in the understanding of some important biology concepts. Nigeria Journal of Education, 2(1), 125-132.

[21] Okoye, N. N. C. (1987). Learner Characteristics and human learning in school. Onitsha: Lead way Books.

[22] Oludipe, D. I. (2012). Gender difference in Nigerian junior secondary students' academic achievement in basic science. Journal of Educational and Social Research, 2(1), 93-93.

[23] Omenge, N.B \&Nasango, J.W. (2010). Effects of Socialization with regard to gender roles and students' academic achievements in secondary schools in Kisiidistrict, Kenya. Maxwell Scientific Organization. Current Research Journal of Sciences vol 2(6) 327-333.

[24] Semple, A. (2000). Learning Theories and Their Influence on the development and Use of Educational Technologies. Australian Science Teachers Journal, 46(3).Retrieved from EBSCO data base.

[25] Shelton, F. (2008).Effective Behaviours Management in the Primary Classroom. McGraw-Hill Education. (UK).

[26] UNESCO.(2015). Improving the Quality and Relevance of Education in Kurdistan. New Delhi, India.

[27] UNESCO. (2009).

[28] UNESCO. (2003). Gender and education for all: The leap to equality. France: UNESCO publishing.

[29] UNESCO (2000).Nigerian educational research and development council.(NERDC)Yaba, Lagos.

[30] Vygotsky, L. (1978). Mind in society: The development of higher psychological processes (Ed. by M. Cole, V. John-Steiner, S. Scribner, \& E. Souberman). Cambridge, MA: Harvard University Press.

[31] Yusuf, A.M. \& Adigun, J.T. (2010). The Influence of School Sex, Location and Type on Students' Performance: International Journal of Education Sciences, 2 (2), 81-85.

\section{AUTHOR'S BIOGRAPHY}

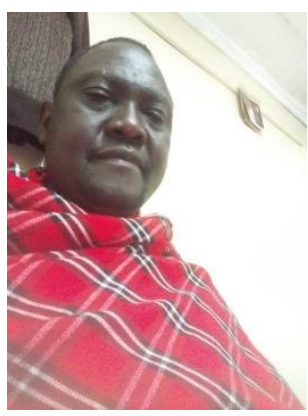

Mr Charles Kisigot, was born on 8th August 1970 in Marinda farm,Kitale. He has a Masters Degree in Education from Moi University Eldoret, a Bachelors degree of Kenyatta University, Diploma (Special Needs Education) from Kenya Institute of Special Education, a Post Diploma Certificate in Educational Audiology, and Primary Teacher Education Certificate (P1). He has taught headed several primary and secondary schools, in a teacher training college and has worked as a Graduate Assistant at CUEA- Gaba Campus. Currently, he is an Education Officer at Uasin-Gishu County, Curricula Support Officer in Charge of SNE programmes.

Citation: Prof. Paul A. Ogula, et.al. " Effects of Gender on Students' Academic Achievement in Public Secondary Schools in Marakwet East Sub County, Kenya" International Journal of Humanities Social Sciences and Education (IJHSSE), vol 8, no. 3, 2021, pp. 01-10. doi: https://doi.org/10.20431/2349-0381.0803001.

Copyright: () 2021 Authors. This is an open-access article distributed under the terms of the Creative Commons Attribution License, which permits unrestricted use, distribution, and reproduction in any medium, provided the original author and source are credited. 